\title{
Nurses' work at Family Health Strategy: possibilities to operate health needs
}

\author{
O trabalho dos enfermeiros na Estratégia Saúde da Família: possibilidades para operar necessidades de saúde \\ El trabajo de las enfermeras en la Estrategia de Salud Familiar: posibilidades de operar las necesidades de salud
}

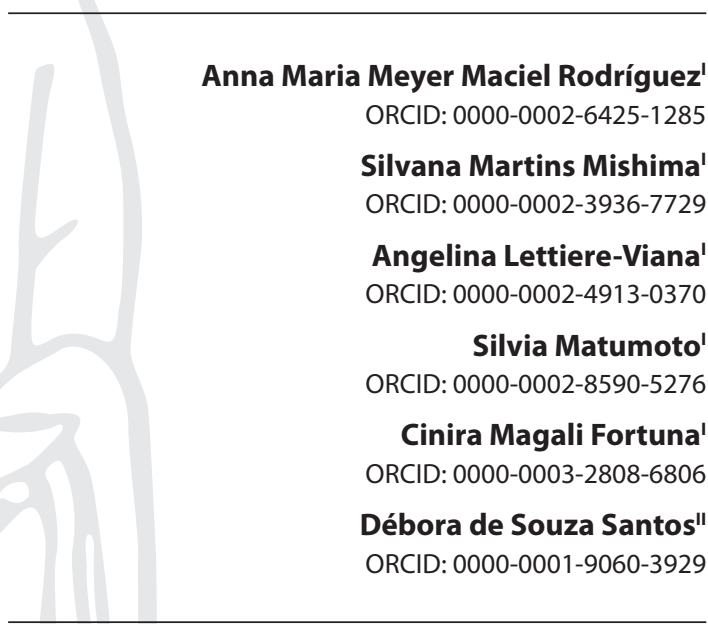

'Universidade de São Paulo. Ribeirão Preto, São Paulo, Brazil. "Universidade Estadual de Campinas. Campinas, São Paulo, Brazil.

How to cite this article:

Rodríguez AMMM, Mishima SM, Lettiere-Viana A, Matumoto S, Fortuna CM, Santos DS. Nurses' work at Family Health Strategy: possibilities to operate health needs. Rev Bras Enferm. 2020;73(Suppl 6):e20190704. doi: http://dx.doi.org/10.1590/0034-7167-2019-0704

Corresponding author:

Anna Maria Meyer Maciel Rodríguez E-mail: nimeyer5@hotmail.com

EDITOR IN CHIEF: Antonio José de Almeida Filho ASSOCIATE EDITOR: Mitzy Reichembach

Submission: $01-18-2020$

Approval: 06-11-2020

\section{ABSTRACT}

Objectives: to identify and analyze possibilities for recognizing health needs in the nurses' work at Family Health Strategy. Methods: a qualitative study with interviews and observation of the nurses' work in the countryside of São Paulo. The empirical material was subjected to thematic content analysis and interpreted in the light of the health work process. Results: two themes emerged: Possibilities utilized and Possibilities neglected to recognize health needs. Careful observation, welcoming, attention, listening, bonding and dialogue developed by nurses, in live work in action with users, touched on the possibilities, which, taken advantage of, were evidenced in care in spontaneous demand, scheduled consultation, examination gynecological and group activities. Final Considerations: nurses are able to recognize health needs, which can expand their clinical practice and interprofessionality in Family Health. Descriptors: Family Health Strategy; Primary Health Care; Work; Nurses; Needs Assessment.

\section{RESUMO}

Objetivos: identificar e analisar, no trabalho do enfermeiro na Estratégia Saúde da Família, possibilidades para o reconhecimento de necessidades de saúde. Métodos: estudo qualitativo, com entrevistas e observação do trabalho de enfermeiros no interior paulista. O material empírico foi submetido à análise de conteúdo temática e interpretado à luz do processo de trabalho em saúde. Resultados: emergiram dois temas: Possibilidades aproveitadas e Possibilidades negligenciadas para reconhecer necessidades de saúde. A observação cuidadosa, o acolhimento, a atenção, a escuta, o vínculo e o diálogo desenvolvidos pelos enfermeiros, no trabalho vivo em ato com os usuários, afloraram as possibilidades, que aproveitadas, foram evidenciadas em atendimento na demanda espontânea, consulta agendada, exame ginecológico e atividades grupais. Considerações Finais: os enfermeiros são capazes de reconhecer necessidades de saúde, o que pode ampliar sua prática clínica e a interprofissionalidade na Saúde da Família.

Descritores: Estratégia Saúde da Família; Atenção Primária à Saúde; Trabalho; Enfermeiros; Determinação de Necessidades de Cuidados de Saúde.

\section{RESUMEN}

Objetivos: identificar y analizar, en el trabajo de las enfermeras en la Estrategia de Salud Familiar, las posibilidades para el reconocimiento de las necesidades de salud. Métodos: estudio cualitativo, con entrevistas y observación del trabajo de enfermeras en el interior de São Paulo. El material empírico fue sometido a análisis de contenido temático e interpretado a la luz del proceso de trabajo de salud. Resultados: surgieron dos temas: Posibilidades utilizadas y Posibilidades desatendidas para reconocer las necesidades de salud. La observación cuidadosa, la recepción, la atención, la escucha, el vínculo y el diálogo desarrollados por las enfermeras, en el trabajo en vivo en acción con los usuarios, tocaron las posibilidades que, aprovechadas, se evidenciaron en la atención en la demanda espontánea, consulta programada, examen actividades ginecológicas y grupales. Consideraciones Finales: las enfermeras pueden reconocer las necesidades de salud, lo que puede ampliar su práctica clínica e interprofesionalidad en salud familiar.

Descriptores: Estrategia de Salud Familiar; Atención Primaria de Salud;Trabajo; Enfermeros; Evaluación de Necesidades. 
Nurses' work at Family Health Strategy: possibilities to operate health needs Rodríguez AMMM, Mishima SM, Lettiere-Viana A, Matumoto S, Fortuna CM, Santos DS.

\section{INTRODUCTION}

The Family Health Strategy (FHS) allows to produce differentiated care to meet not only health demands, but, fundamentally, the needs of users of Primary Care (PC) in Brazil. The health practices performed by the FHS teams in the territories entered are very close to the context of people's lives ${ }^{(1)}$. Especially of social determinants, taken as conditions of different natures that interfere in their way of being, living and becoming ill(2).

This approach can facilitate workers' understanding of the conformation of health needs that refer to having good living conditions; guaranteeing access to technologies that improve and prolong life; the bond with a health professional or team; and autonomy and self-care in choosing the way to lead life ${ }^{(3)}$. At the same time, it can qualify the worker-user relationship and favor the production of more assertive health care ${ }^{(2)}$.

Often, these aspects appear interwoven in the form of a specific demand that fits the offer of actions and services made available by health units, which, guided by the current model of care, translates into the service of a specific complaint. This may disguise a more complex need, involving several issues in addition to the person's biological functioning, which can be perceived and understood by the professional with a broader view of the health-disease process ${ }^{(4-5)}$.

The conception of demands and needs can be represented by the image of an iceberg, in which the submerged part corresponds to a specific demand and the submerged part corresponds to health needs. A demand does not always carry or hide a need that needs attention or strictly clinical intervention. When this happens, the needs may not be recognized or identified in the demand expressed by users.

In this way, the importance of recognizing needs is associated with the person-centered care guidelines, longitudinality and comprehensive care proposed by FHS and PC ${ }^{(1)}$. This is one of the reasons why recognizing needs through demands seems to be one of the ways to reorganize the logic of care production and service organization, still under the hegemonic perspective, which maintains the centrality in the disease $\mathrm{e}^{(6)}$.

In this sense, it is understood that the ways to recognize the needs can be initiated at work through knowledge, attitudes and skills developed in the professional-user relationship, when the demand is presented to each other. Thus, workers exercise their self-government and offers care influenced by the care model, work organization and professional autonomy ${ }^{(7)}$.

Taking the conceptions of the micropolitics of health work ${ }^{(7)}$, which are based on the discussion of the health work process ${ }^{(8)}$, the possibilities at work to recognize the needs have a theoretical support close to the concept of fold ${ }^{(6-7)}$. This expression is characterized by a movement in interpersonal relationships, at the moment of performing live work, i.e., work in action where there is an autonomous and creative expression of workers producing care actions. This movement redraws, potentially, a path and opens up new possibilities to produce something different from the usual ${ }^{(6-7)}$.

According to the theoretical framework of the health work process $^{(8)}$, men (generally) with needs arrive at health facilities; and present this need that may or may not be met by the action of the team professionals. Authors ${ }^{(4)}$ state that men can present needs as well as health demands that can determine the production of care guided by a certain purpose put to work.

One way to recognize health needs is through active listening $^{(9)}$, qualified listening ${ }^{(4)}$ or listening ${ }^{(10)}$ to service users. These technologies allow the worker to perceive users in a broad way in the different dimensions of the health-disease process ${ }^{(4,9-10)}$. These actions are not mechanical or standardized in protocols, they depend on the availability and willingness of workers to place themselves differently in live work in action. It is understood, therefore, that workers who are willing to listen to users in their meeting will be able to identify on demand something more that deserves attention, thus decoding the hidden need.

Nurses are recognized as one of the workers with the potential to develop competence to promote, in the team as a whole, intervention and reflection movements in order to achieve comprehensive care in order to approach users holistically and identify health needs. Moreover, nurses may be able to plan, execute, integrate and optimize different care and intervene in social determinants of the health-disease process in the $\mathrm{FHS}^{(11-12)}$.

\section{OBJECTIVES}

To identify and analyze possibilities for recognizing the health needs of users and/or their families in the nurse's work at FHS.

\section{METHODS}

\section{Ethical aspects}

The investigation respected the ethical precepts established by Resolution 466 of December 12, 2012 of the Brazilian National Health Council (Conselho Nacional de Saúde). The Research Ethics Committee approved the study, under Opinion 2,493,133.

In the presentation of results, the nurses interviewed were identified by letter $\mathrm{N}$, followed by the number that indicated the increasing order of the interview (N2 to N32); N1 was the pilot interview. The nurses observed were designated as ON1, 2 and 3 ; and the observations made in the Family Health Units (FHUs) were designated as OBS of FHU1, 2 and 3.

\section{Type of study}

This is a qualitative study guided by the Consolidated Criteria for Reporting Qualitative Research ${ }^{(13)}$, with theoretical support in the health work process ${ }^{(7)}$.

\section{Study setting}

The research was carried out in FHUs in the municipality of Ribeirão Preto, state of São Paulo, Brazil.

\section{Data source}

The existing $20 \mathrm{FHUs}$ are made up of 46 teams spread across the five health districts in the municipality. Each team has a nurse; therefore, 46 nurses work in the municipality's FHS in this care modality. Of the 46 nurses, 39 were present at FHUs during the 
Nurses' work at Family Health Strategy: possibilities to operate health needs Rodríguez AMMM, Mishima SM, Lettiere-Viana A, Matumoto S, Fortuna CM, Santos DS.

period established for data collection, among which, 31 accepted to participate.

\section{Collection and organization of data}

One of the authors of the investigation collected the data through semi-structured interviews and participant observation of the work. Initially, 31 nurses were interviewed at their workplace, according to their availability. They answered interview script questions about users' demands and needs and about the work process in the context of FHS. The interview time ranged from 28 minutes to 01 hours and 25 minutes, held from April to October 2017.

In order to make observations, aspects of the work related to good practices in the FHS were identified in the interviews, with a view to comprehensive care. In other words, nurses were observed who shared, in the interviews, statements that referred to the performance developed from the perspective of comprehensive care, organized according to the identification of users' health needs ${ }^{(4)}$. Thus, seven nurses in three different FHUs were selected and observed in their work routine for a week, through an observation script with aspects focused on the organization, dynamics and purpose of the action/situation observed, agents and communication between them.

There were 99 hours of observation, 33 hours on average in each of the three FHUs. The observations were made between March and April 2018. The observation time ranged from five minutes to 02 hours and 15 minutes. The actions-reactions of those involved and the observer's impressions were noted in a field diary.

\section{Analysis of data}

The interviews were audio recorded and the content was transcribed in full, validated by the interviewees, submitted to thematic content analysis ${ }^{(14)}$. In the first stage of analysis, an attempt was made to approach the content of the interviews with skimming of the material. Then, the corpus was constituted, by answering criteria of exhaustiveness, representativeness, homogeneity and pertinence ${ }^{(14)}$ and, later, definition of context and meaning units. These elements were corrected, discussed and validated by the authors, identifying two thematic categories: Possibilities utilized and Possibilities neglected in the nurses' work to recognize health needs.

The set of interviews comprised the main corpus of the study, which was compared to that of the observations (secondary corpus) using data triangulation ${ }^{(15)}$. The observations complemented the interviews and allowed the analysis of the situation observed in what happens in the act and in the occurrence of contradictions.

\section{RESULTS}

\section{Possibilities utilized in the nurses' work to recognize health needs}

Nurses developed knowledge, skills and attitudes to advance the recognition of the implicit (needs) beyond the explicit (demands), brought by user in spontaneous demand care, scheduled consultations, gynecological examination and health education groups.

N15 shares a meeting in which the user came to the FHU with a complaint of menstrual delay. During the conversation, the professional shows availability to listen to the young user and to know her life context, collecting data to develop health care. This capacity, mobilized at the meeting, allowed N15 to identify needs, in addition to demand, that deserved intervention. Thus, he provided guidance on sexually transmitted infections, condom use, Pap smears, in addition to recognizing the importance of the action of another team member, the doctor, to prescribe birth control pills.

There was a person who arrived with a complaint of menstrual delay and was a young woman. We started talking, she took the pregnancy test, it was negative, but then I started to see that she started sexual intercourse four years ago; she had never been to the doctor; she had never done Pap smears; she was not using any contraceptive method; and her current boyfriend had just left the Brazilian Juvenile Detention Center, who she barely knew, they had only been together for two months. She came with this delay complaint, but we could see that there were other things that we needed to be investigating there. So, I already ordered the exams, the serologies, we prescribed the contraceptive, I already advised about the condom and I already scheduled an appointment. She only came to do the test, but we were able to provide a more global service and we already scheduled Pap smear too. (N15)

N9 states that the Pap smear is not restricted to the performance of the technical procedure, recognizing the potential of the meeting to identify health needs and raise aspects of the user's life context. N9 reports having availability and interest to hear the user's life story and subjectivities, which initially shows surprise with her attitude. N9 also guides her on the possibility of resolving family conflicts.

The person comes to collect cytology and then l ask if there are any complaints, it is part of our consultation and the person asks "how so?" She thinks it has to be something gynecological and I ask "in relation to life, would you like to say something that is bothering you?" This question opened up for the patient to tell about a conflict with her daughter, with her partner, with her daughter's husband. She was in the middle of a major family conflict in which she realized that she abandoned herself. She counted, stopped and said "I think I forgot who I am, what I like to do. That's why I'm in anguish. I hardly even came today because I was so bad that I didn't even want to get out of bed, but now I'm realizing that I forgot about myself ". I said "make a letter for you". I did a little mental health interview "talk to user $X$ who you were five, ten years ago". Then, I booked a week later. She came with a letter with Portuguese errors, very simple, but she managed to sit and talk with her daughter, with the companion who comes to live with her next week so she needed to listen. In a context of cytology collection, it is these meetings that favor health, which is very special for me to be able to feel that that person is there all over, that he is not a cervical cancer, that I am concerned with quantifying. But do not miss the opportunity to be whole and it also. (N9)

N10 reports a group activity in which one of the participants seeks to share a family circumstance. N10 guides user on how 
Nurses' work at Family Health Strategy: possibilities to operate health needs Rodríguez AMMM, Mishima SM, Lettiere-Viana A, Matumoto S, Fortuna CM, Santos DS.

to care for her daughter-in-law at the FHU. This situation shows a possibility used by the nurse to recognize the health needs of a family member who was not present in the group. This action was carried out through the nurse's attention to user.

It was a group that I did Pap smear, I put all Pap smear from six months ago. Out of 69, 20 came, and the normal results I delivered and the altered ones stayed with the doctor. But on the day the doctor got sick and didn't come, but I had to solve all the problems. From this service, a woman came with a story that her 15-year-old son was dating, was having a relationship and they were not using any method. Then this girl came to take the test and I managed to bring this girl, because she also had a resistance. The day she came for the test, she came with her mother-in-law, so we were able to talk about a method for her. (N10)

In another meeting, N20 seems to recognize other needs, in addition to the user's initial demand, assessing them as the solution of another team member. N20 seeks to articulate its technicalscientific knowledge with that of the doctor, sharing user care.

If I am in service and I see that there is a complaint, some demand that goes beyond what I can intervene, I ask the doctor for help to assess with me, to help me with the conduct, understand? I often do shared care with the doctor or another professional on the team. When I see that it goes beyond what I can do, I need complementary work [...]. If I'm doing a Newborn Bloodspot Screening Test, I examine the child and I see if the puerperal woman has a complaint of fever or local infection, mastitis. I guide milking, breast care, breastfeeding, but sometimes, with mastitis, he needs antibiotics, so, I request a medical assessment for medication application. (N20)

One of the observations in FHU 2 depicts the meeting between ON1 and the user who came for a scheduled medical consultation. At the reception, ON1 makes a careful observation of the movement of the FHU and, using the bond built with a user and her family, perceives the user's unusual behavior and calls her to talk, welcoming her to the office.

ON1 greets the user at the reception and comments to the observer: I think so-and-so is not doing well today. ON1 checks the system that the user has a medical appointment at 8 am and asks her to accompany her to her office. ON1 asks "what's going on, so-and-so?" People sit down and the user tells what is happening, starts to cry and sob. User says he is abstaining from a medication. ON1 says "I think this is the whole story you are going through. What are you feeling? Numbness, dizziness, shortness of breath, anguish?" User responds "chest pain. The doctor sent a request to a psychologist, but it takes time, right?" ON1 replies "do you feel like killing yourself?" User responds "no, because I have God in my heart. So-and-so, I told my son that he needs to go to [name of the hospital] to remove those plaques." ON1 says "has he been to the orthopedist yet?" User answers "yes, my son needs help, but he has to want it". And user ventes about the problems about the child who is an alcohol and drug user. ON1 listens carefully to the user who wipes her tears. ON1 says "you could go to CAPS-AD, there they take care of the family too, because the psychologist here will take a while. When we have an alcohol and drug user at home, we are abused and become fragile. There they help the family and the user, it's an open door to take care of the base. They're prepared for that. You're getting sick together with your son. He chose this life and not you. You need to go there, otherwise you will sink. For what medicine did you change?" User says "Clonazepam". ON1 explains the use of the medication [...]. User says "so-and-so do you think what I'm feeling is emotional?" ON1 reinforces "go to CAPS-AD, there they will help you." ON1 checks the schedule and says "come on, so-and-so?" The two leave the office, say goodbye and the user sits in the waiting to wait for the doctor's call. (OBS of FHU 2)

In another observation at FHU 2, during the nursing consultation, ON1 performs auriculotherapy while demonstrating availability to listen to the current history of the user and the reason for requesting a medical document. In attendance, the user does not recognize this meeting as a potential space for listening and dialogue, defining it as a moment where "there is small talk".

User enters the office, greets ON1 and is very comfortable, settles in one of the chairs and starts talking about his food. User says he also came to the unit to get a report from the doctor. ON1 listens to the user's doubts and prepares the material to perform auriculotherapy. ON1 says "I'm feeling the lady more willing, more excited". User responds "I am, I am taking omega 3 and this thing you are doing with me, it is also helping [referring to auriculotherapy]". User tells about his relationship with his grandson. ON1 performs auriculotherapy and asks "what report is this that you came to get?" User says "it is to take to prison X and there they will see if my son goes to the doctor". ON1 and the user talk about the son's judicial sentence and his relationship with the grandson and the user's difficulties in taking care of the grandson, since the boy's mother abandoned the child. ON1 asks how the boy feeds and the user responds. User says that the grandson is hyperactive and that she can't stand running after him [...]. ON1 says "try putting him in physical activity. It could be a way out". User responds "but where am I going?" ON1 says "I will see it. Maybe in [name of the park] or in some social project. I will see it with the physical educator later I will tell you". User says "God will help me through this phase [and talk a little more about healthy eating]". User says "now let me go there and wait for the doctor, we small talked already. Bye, nurse!" ON1 says "bye, so-and-so". (OBS of FHU 2)

\section{Possibilities neglected in the nurses' work to recognize health needs}

The testimonies and observations reveal possibilities for the recognition of health needs, in the meetings between nurses and users, which were neglected by professionals. Nor did they develop knowledge, skills and attitudes to move towards comprehensive care, which indicates contradictions present at work.

N5 claims that the search for consultations by users with hypertension and diabetes is small and when they schedule, they do not attend the consultations. N5 seems to limit the development of his work within the physical structure of the FHU.

Within what we call a health consultation, the demand is very small. It is precisely those patients who would need not only to prevent secondary problems, but even to prevent diseases such as hypertension, diabetes, and they don't look for care. I thought I would have an easier penetration, but I can't, because they book and don't come. So, this is very complicated. (N5) 
Nurses' work at Family Health Strategy: possibilities to operate health needs Rodríguez AMMM, Mishima SM, Lettiere-Viana A, Matumoto S, Fortuna CM, Santos DS.

In the same direction, N3 does not seem to recognize the potential of meeting with users who are missing appointments and who subsequently appear in spontaneous demand. N3 points out that these users demand immediate clinical care on a given day, but their demand is not always classified as a priority in medical care. This attitude, which fits unscheduled care standardization, does not seem to favor listening to users' problems, blaming them for their health condition and their choices.

I think that patients' demands are incompatible with what the service provides. They come here and want to be attended to on the day. I don't have an appointment that day. But I get in their appointments and they have three absences behind. But on that day, they want to be served and for something that by the risk stratification does not enter the service of the day. So, I have to schedule again, and they miss the appointment again. It's complicated (N3).

N25 states that in a cytology exam it is common for users to bring several demands to be resolved. In this situation, N25 selects those of less complexity to be answered at that moment, scheduling the user with another professional on the team who will assess other demands at other times. N25 also seems to block attitudes and skills that could favor the investigation of possible needs brought about by clinical demands, for which care is provided.

The woman comes to collect the cytology, which is late, a breast exam for us to do, and the patient says "oh, but I have leg pain, stomach pain, headache". So, we try our best to solve this problem for all patients. But for most people we have to say "look, today we are here to focus on this type of service, you can't see everything. Let's see this and one more thing [...]". Or we even leave a patient scheduled, but every day there are patients who come to bring their child and enjoy the consultation and say "ah, but taking advantage of the fact that I'm here, I'm also feeling this". (N25)

The user's autonomy in not adhering to the treatment proposed by the team bothers N24 and hinders their work. N24 clarifies that making the user understand the importance of changing habits is frustrating, as he does not accept the proposal indicated by the team. N24 does not seem to be interested in knowing the user's life context and establishing relationships between technical guidelines and the user's difficulties/facilities in adhering to treatment.

Perhaps, what is very complicated, is working with patients, trying to make them understand that to improve their health, they need to change their habits. This I know that, in the long run, sometimes it will not happen. So, I think it frustrates patients not to adhere to treatment. I think this is the biggest difficulty. (N24)

In one of FHU 1's observations, the welcoming attitude, dialogue and listening to ON2 are restricted. ON2 and user meeting seems to have been run over by the technical risk classification criteria for urgent and emergency care and by the biomedical organization of work at FHU.

An employee enters the office and says to ON2 "there has been a girl with vaginal bleeding for three days and she needs to go the health center urgently". ON2 says aloud "if she is bleeding like that, she has to go to the District for emergency care, because here patients can wait". Employee insists "I think she is not doing well". ON2 goes to the gynecological pre-consultation room and finds the user sitting on her cell phone. ON2 comes in and asks in a loud voice "what's going on?" [and takes the sphygmomanometer and stethoscope to check the user's blood pressure]. User says he has been bleeding for many days and that last week he was in the District and the doctor passed diclofenac which cut the bleeding and had already taken two pills. ON2 says aloud "diclofenac is not to stop bleeding". User says "but I took two, and it passed". ON2: responds "are you bleeding now?" User responds back "no, not now. But the doctor there sent me to look for the health center to take tests and go to consultation" [and tries to explain the whole situation]. ON2 talks to the user in a harsh tone, explaining the signs of shock and the flow of care in cases of urgency and emergency, and user begins to cry. ON2 is touched by the user's emotional fragility and repeats the technical guidelines she had made in a more welcoming tone of voice. ON2 says "here you can go to the health center, but it will take time, just after noon". ON2 and employee look at each other and employee nods negatively. ON2 says "can you wait?" User wipes away tears and says yes with her head. ON2 leaves the room and goes to the office. After an hour and a half, a user appears at the office door, calls the observer and says "it worked, see?" Observer asks "what did the doctor say?" User responds "he asked for an ultrasound, gave me this medicine here [shows the prescription] and asked me to come back with the exam to see what it is". Observer says "oh, good". User nods positively and leaves FHU. (OBS of FHU 2)

\section{DISCUSSION}

In the first set of speeches and observations referring to the first thematic category, there are evidenced different possibilities used by nurses to recognize health needs, in addition to the demands initially brought. The needs referred to the aspects addressed by the Taxonomy of Health Needs ${ }^{(3)}$. They were identified by relevant proactive skills and/or attitudes for users' health monitoring ${ }^{(16)}$.

This set of actions was developed through soft technologies, such as careful observation, reception, attention, dialogue, listening, and bonding. Nurses also assumed the relevance of the intervention of other team professionals and other services in the care network, articulating care. All these aspects allowed the recognition, in action, of the users' health needs. For users, the possibility of listening and dialogue in nursing consultations, reinforces the bond, brings confidence and encouragement to talk about their health needs ${ }^{(9)}$. Thus, adopting an open attitude towards the social interaction between nurse-user can redirect the way users are interpreted when they seek health care in the current model of care.

If nurses perceive users in their life context, they will be able to capture something beyond what is brought to them by a demand. Thus, they will identify needs that require new care, making room for differentiated health practices ${ }^{(17)}$. In the exposed results, one can identify an alternative care, auriculotherapy, which can be grouped with the set of non-traditional health techniques performed also in another Brazilian $\mathrm{FHU}^{(18)}$. In the space for carrying out this alternative care, a contradiction is established. At the same time that this procedure permeates nurses' proactive 
Nurses' work at Family Health Strategy: possibilities to operate health needs Rodríguez AMMM, Mishima SM, Lettiere-Viana A, Matumoto S, Fortuna CM, Santos DS.

skills and attitudes, users reproduce the biomedical perspective of attention: "we already small talked".

This care model, also called medical-hegemonic, curative or rational, is a set of interests that exalts a certain knowledge to the detriment of other technical-scientific knowledge that can also contribute to reading health needs. Hegemonic arrangements are relevant, being effective in producing timely responses to users. But they are not enough to accommodate demands and needs regarding the socio-family context and the subjectivities of users ${ }^{(19)}$.

Sharing care among team members seems to show work interaction, integration and articulation, which allows planning assistance more assertively and solving the demands and needs of users ${ }^{(20-21)}$. Co-participation in the care production and the socialization of different practices and knowledge can break with the fragmentation of work and favor interprofessionality ${ }^{(22)}$ and comprehensive care.

In this sense, the FHS, due to its specificities, seems to open possibilities for nurses to develop and seek relevant technological knowledge to identify needs and develop comprehensive and longitudinal care focused on person ${ }^{(1)}$.

It is understood, therefore, that in this movement of detecting and taking advantage of possibilities at work to advance the demands towards health needs, it is possible to expand the clinical practice of nurses in user care; provide and articulate new actions with the team in building interprofessional practice; and manage care in PC, with a view to access and quality of care ${ }^{(23-25)}$.

Nurses seem to recognize the importance of expanded clinical practice that has been developed along with other practices in the current care model to respond to users' health needs. But its implementation is still a challenge, as this action breaks with the strict objectivity of the work, showing subjectivities in process (feelings, meanings, intimacy, desires, vulnerabilities) that represent the way of thinking, acting, and being of people in the world(26). These subjective aspects are dynamic, are not included in protocols and require rearrangement and (re)combination of other technologies in the development of nurses' expanded clinic $^{(27)}$.

It is important to note that since the 1990s, the complexity, dynamics, diversity and subjectivity of health needs have been studied. This reinforces, at the same time, the idea that their care goes beyond the sphere of clinical, curative and individual intervention, requiring multifaceted intervention in developing the health work process ${ }^{(28)}$.

In the second set of results referring to the neglected possibilities, in the nurses' work, to recognize health needs, aspects of the Taxonomy of Health Needs ${ }^{(3)}$ were also related, mostly translated in the form of health demands. They seem to have been exposed in a reactive pattern of work organization. Users are the ones who go to the FHU to schedule an appointment when they want or need, according to the availability of places, with individual medical consultation being the main form of clinical care ${ }^{(29)}$.

Nurses do not seem to relate the absence of users in consultations with the health and epidemiological responsibility of the team for the population enrolled ${ }^{(16)}$. This could trigger actions to identify the causes of absenteeism and possibly reduce these absences, in addition to contributing to the management and planning of actions and services at $\mathrm{FHU}^{(30-31)}$.
The association of this reality with the organization of work allows a reflection: does the time imposed for scheduling the consultation favor the users' visit to the FHU or does it only contemplate the availability of professionals who schedule consultation? Aware of absenteeism, nurses could request a visit from the community agent to the defaulting users to detect the reason for their absence, demonstrating technical commitment and an attitude of care and not necessarily of control(31).

Still, depending on clinical situation of users, nurses could schedule a home visit, seeking to establish a different link for health monitoring. In this sense, the FHS has the power to break through the walls of the units. Professionals mobilize in activities outside FHUs in search of relational and social specificities that conform health demands and needs ${ }^{(5,32)}$.

Another characteristic of this set of results is the use of selective and classificatory listening ${ }^{(6)}$, which does not favor dialogue and the recognition of health needs. Still, in user care, cast and fragmented, each professional solves a specific part of the demand brought by him or her ${ }^{(19)}$. According to some nurses, autonomy and self-care in choosing the way to lead one's life seem to be unrelated to the subjective and dynamic production of health needs ${ }^{(3)}$.

This understanding seems to reinforce the verticalization of nursing actions. The guidelines of knowledge holders must be followed by those who do not have them and only workers know and decide what is most appropriate to maintain the health of users $^{(29)}$. Contradictorily to this idea, nurses at a Primary Care Center in the United Kingdom reveal that they do not impose their guidelines on users, but offer them relevant information for more conscious decision-making about their health ${ }^{(9)}$.

In this setting, the question emerged: in a context of vulnerability and social exclusion that affects a large part of the population assigned to Brazilian FHUs, users have access to the team's proposals, since precarious living conditions determine adherence or not, to treatments and to user autonomy and self-care? ${ }^{(33)}$

Another issue is blaming users, whether for the health problem presented, for their choices or for the ways of living and working in society. Blaming reduces health demands and needs to individual behavior without establishing relationships with the social determinants of the health-disease process ${ }^{(30)}$.

Implicitly, work standardization guides, protocolically, health practices in some of the FHUs. It establishes when, how and who will be served, disregarding the will, needs and autonomy of users with respect to their own health. These standardized and unidirectional actions reap users' subjectivity and individuality, limit their service and reinforce the biomedical model of care $\mathrm{c}^{(30,33)}$.

Workers seem to perceive users not as subjects with needs (their object of work) ${ }^{(7)}$, but as maladjusted biological machines for which the repair will be provided, fitting the users' demand into the pre-determined routine characteristic of the biomedical perspective ${ }^{(17)}$. Therefore, organization and operationalization of the work process based on biomedical clinical criteria do not seem to allow the identification of needs disguised in health demands. Some nurses neglected possibilities to recognize the subjectivities in process and the particularities of specific demands that could open up to other interventions in the set of their duties and that of the team members. 
Nurses' work at Family Health Strategy: possibilities to operate health needs Rodríguez AMMM, Mishima SM, Lettiere-Viana A, Matumoto S, Fortuna CM, Santos DS.

\section{Study limitations}

As a limitation, the impossibility of generalizing the research results is indicated. FHS population coverage in the municipality is low, reflecting its slow progression in southeastern Brazil. This region still has traditional basic units as the main gateway to the health system ${ }^{(34)}$.

\section{Contributions to health, nursing, and public policies}

The investigation signals contributions to health, nursing, and public policies, as they point out possibilities, in the work of nurses at FHS, to identify distinct and complex health needs brought by users and/or families and to offer other answers in addition to pre-established actions. At the same time, these propositions can support professional development processes to support the construction, development and implementation of performances to identify health needs.

The movement to detect possibilities at work and recognize health needs is a dynamic, permanent and ongoing learning. This movement can expand the clinical practice of nurses in the set of their duties. Considering the potential of nurses'work and team work in detecting and meeting users' needs, from the perspective of comprehensive care, it can be said that the findings of this investigation are consistent with the attributes of longitudinality and centered care in person proposed by the $\mathrm{FHS}^{(1)}$.

\section{FINAL CONSIDERATIONS}

The possibilities for recognizing health needs happen in live work on the fly. This movement is permeated by soft technologies that help nurses to recognize implicit needs hidden in explicit demands. Thus, when recognizing health needs, differentiated care is produced and articulated by nurses who point out new paths for practices in the current model of care. Such care can be constructed both in the nurse's clinical practice and in interprofessionality in the FHS.

Some nurses neglected the occurrence of these possibilities at work. These professionals seem to have denied knowledge, skills and attitudes, translated by the recognition of the relevance of interprofessional work and care network services through incorporating listening, dialogue, welcoming, careful observation and bonding, used to bring about this movement. This reality reaffirms the logic of biomedical work that reduces users to the response of their specific demand, which often blames them for their way of facing their health and disease problems.

Considering the results and contributions of the study, which go beyond the nursing field, training and interprofessional training are credited with qualifying the clinical practice of nurses and other FHS professionals, in order to recognize the possibilities for identifying health needs. Such training can offer technological resources, which qualify the action of these workers, for the development of capacities to be mobilized in the meetings with users to recognize the needs that present themselves in demands; and understand the conformation of health needs and the health-disease-care process. Furthermore, it can assist in understanding the role of FHS and in identifying the contradictions present in daily work.

\section{FUNDING}

Coordination for the Improvement of Higher Education Personnel (CAPES - Coordenação de Aperfeiçoamento de Pessoal de Nível Superior - Brazil), Financing Code 001, by the doctoral scholarhip $n^{\circ}$ 1.639.716.

National Council for Scientific and Technological Development (CNPq - Conselho Nacional de Desenvolvimento Científico e Tecnológico - Brazil), Process n³09826/3017-9.

\section{REFERENCES}

1. Ministério da Saúde (BR). Portaria n. 2.436, de 21 de setembro de 2017. Aprova a Política Nacional de Atenção Básica, estabelecendo a revisão de diretrizes para a organização da Atenção Básica, no âmbito do Sistema Único de Saúde (SUS) [Internet]. Brasília, DF: Ministério da Saúde; 2017 [cited 2019 Aug 19]. Available from: http://bvsms.saude.gov.br/bvs/saudelegis/gm/2017/prt2436_22_09_2017.html

2. Tong ST, Liaw WR, Kashiri PL, Pecsok J, Rozman J, Bazemore AW, et al. Clinician experiences with screening for social needs in primary care. JABFM. 2018;31(3):351-63. doi: 10.3122/jabfm.2018.03.170419

3. Cecílio LCO, Matsumoto NF. Uma taxonomia operacional de necessidades de saúde. In: Pinheiro R, Ferla AF, Mattos RA, organizadores. Gestão em redes: tecendo os fios da integralidade em saúde [Internet]. Rio de Janeiro: CEPSC/IMS/UERJ/EDUCS; 2006 [cited 2019 Aug 29]. p. 1-8. Available from: https://pt.scribd.com/ document/379389202/1-UMA-TAXONOMIA-OPERACIONAL-DE-NECESSIDADES-DE-SAU-DE-Cecilio-Matsumoto-2006

4. Pinheiro R, Mattos RA. Os sentidos da integralidade na atenção e no cuidado à saúde [Internet]. Rio de Janeiro: CEPESC/IMS/UERJ/ABRASCO; 2009 [cited 2019 Aug 22]. Available from: https://cepesc.org.br/wp-content/uploads/2013/08/Livro-completo.pdf

5. Oliveira MAC, Silva TMR. Health needs assessment: a requirement for qualifying health care. Rev Bras Enferm. 2012;65(2):203. doi: 10.1590/ S0034-71672012000200001.

6. Abrahão AL, Merhy EE. Healthcare training and micropolitics: concept tools in teaching practices. Interface. 2014;18(49):313-24. doi: 10.1590/1807-57622013.0166.

7. Merhy EE. Em busca do tempo perdido: a micropolítica do trabalho vivo em ato, em saúde. In: Franco TB, Merhy EE, organizadores. Trabalho, produção do cuidado e subjetividade em saúde [Internet]. São Paulo: Hucitec; 2013 [cited 2019 Sep 10]. p. 19-67. Available from: https:// www.researchgate.net/publication/33023414_Em_busca_do_tempo_perdido_a_micropolitica_do_trabalho_vivo_em_saude 
Nurses' work at Family Health Strategy: possibilities to operate health needs Rodríguez AMMM, Mishima SM, Lettiere-Viana A, Matumoto S, Fortuna CM, Santos DS.

8. Mendes-Gonçalves RB. Práticas de saúde: processo de trabalho e necessidades. In: Ayres JR, Santos L, organizadores. Saúde, sociedade e história [Internet]. Porto Alegre: Rede Unida; 2017 [cited 2019 Aug 14]. p. 298-374. Available from: http://historico.redeunida.org.br/editora/ biblioteca-digital/colecao-classicos-da-saude-coletiva/SaudeSociedadeeHistoria.pdf

9. Barratt J, Thomas N. Nurse practitioner consultations in primary health care: patient, carer, and nurse practitioner qualitative interpretations of communication processes. Primary Health Care Res Dev. 2019;20(e42):1-9. doi: 10.1017/S1463423618000798

10. Moraes PA, Bertolozzi MR, Hino P. Perceptions of primary health care needs according to users of a health center. Rev Esc Enferm USP. 2011;45(1):19-24. doi: 10.1590/S0080-62342011000100003

11. Backes DS, Backes MS, Erdmann AL, Büscher A. [The role of the nurse in the Brazilian Unified Health System: from community health to the family health strategy]. Ciênc Saúde Coletiva. 2012;17(1):223-30. doi: 10.1590/S1413-81232012000100024 Portuguese.

12. Forte ECN, Pires DEP, Scherer MDA, Soratto J. Muda o modelo assistencial, muda o trabalho da enfermeira na Atenção Básica? Tempus [Internet]. 2018 [cited 2019 Aug 14];11(2):53-68. Available from: http://www.tempusactas.unb.br/index.php/tempus/article/view/2338/1795

13. Tong A, Sainsbury P, Craig J. Consolidated criteria for reporting qualitative research (COREQ): a 32 -item checklist for interviews and focus groups. Int J Qual Health C. 2007;19(6):349-57. doi: 10.1093/intqhc/mzm042

14. Minayo MCS. O desafio do conhecimento: pesquisa qualitativa em saúde. São Paulo: Hucitec; 2014.

15. Driessnack M, Sousa VD, Mendes IAC. An overview of research designs relevant to nursing: part 3: mixed and Multiple methods. Rev LatinoAm Enfermagem. 2007;15(5):1046-9. doi: 10.1590/\$0104-11692007000500025

16. Cowley S, Houston A. Contradictory agendas in health visitor needs assessment: a discussion paper of its use for prioritizing, targeting and promoting health. Primary Health Care Res Dev. 2004;5(3):240-54. doi: 10.1191/1463423604pc209oa

17. Ilha S, Dias MV, Backes DS, Backes MTS. Professional-patient bond in a team of the family health strategy. Ciênc Cuid Saúde. 2014;13(3):55662. doi: 10.4025/cienccuidsaude.v13i3.19661

18. Oliveira AKS, Bezerra IMP, Silva CC, Lima Neto EA, Silva ATMC. Alternative experiences rescuing knowledge for working processes in health. Rev Esc Enferm USP. 2012;46(4):953-9. doi: 10.1590/S0080-62342012000400024

19. Merhy EE, Feuerwerker LC. Novo olhar sobre as tecnologias de saúde: uma necessidade contemporânea. In: Merhy EE, Baduy RS, Seixas CT, Almeida DES, Slomp Jr H, organizadores. Avaliação compartilhada do cuidado em saúde: surpreendendo o instituído nas redes [Internet]. Rio de Janeiro: Hexis; 2016 [cited 2019 Aug 31]. Vol. 1, p. 59-72. Available from: http://historico.redeunida.org.br/editora/biblioteca-digital/colecao-micropolitica-do-trabalho-e-o-cuidado-em-saude/ politicas-e-cuidados-em-saude-livro-1-avaliacao-compartilhada-do-cuidado-em-saude-surpreendendo-o-instituido-nas-redes

20. Costa ER, Kolhs M, Frigo J, Busnello G. Tasks performed by professional nurses in family health strategy. Rev Enferm UFPE. 2013;7(9):5421-6. doi: 10.5205/reuol.3529-29105-1-SM.0709201308

21. Fernandes HN, Thofehrn MB, Porto AR, Amestoy SC, Jacondino MB, Soares MR. Interpersonal relationships in work of multiprofessional team of family health unit. Rev Pesqui: Cuid Fundam. 2015;7(1):1915-26. doi: 10.9789/2175-5361.2015.v7i1.1915-1926

22. Ellery AEL, Pontes RJS, Loiola FA. Common field of expertise of professionals in the Family Health Strategy in Brazil: a scenario construction. Physis. 2013;23(2):415-37. doi: 10.1590/S0103-73312013000200006

23. Felli VEA, Peduzzi M, Leonello VM. Trabalho gerencial em enfermagem. In: Kurcgant P, organizadora. Gerenciamento em enfermagem. Rio de Janeiro: Guanabara-Koogan; 2016. p. 21-32.

24. Pan American Health Organization. Expanding the roles of nurses in primary health care [Internet]. Washington, DC: PAHO; 2018 [cited 2019 Aug 19]. Available from: http://iris.paho.org/xmlui/ bitstream/handle/123456789/34958/9789275120033_eng. pdf?sequence=6\&isAllowed $=y$

25. Peduzzi M, Aguiar C, Lima AMV, Montanari PM, Leonello VM, Oliveira MR. Expansion of the interprofessional clinical practice of Primary Care nurses. Rev Bras Enferm. 2019;72(Suppl 1):121-8. doi: 10.1590/0034-7167-2017-0759

26. Oliveira AE, Trindade E. Notes about the subjectivity and the subjective processes in the modern world and their impact on clinical psychotherapeutic. Rev Psicol Saúde [Internet]. 2015 [cited 2019 Sep 10];7(1):30-8. Available from: http://pepsic.bvsalud.org/pdf/rpsaude/ v7n1/v7n1a05.pdf

27. Matumoto S, Fortuna CM, Kawata LS, Mishima SM, Pereira MJB. Nurses' clinical practice in primary care: a process under construction. Rev Latino-Am Enfermagem. 2011;19(1):123-30. doi: 10.1590/S0104-11692011000100017

28. Schraiber LB, Mendes-Gonçalves RB. Necessidades de saúde e Atenção Primária. In: Schraiber LB, Nemes MIB, Mendes-Gonçalves RB. Saúde do adulto: programas e ações na unidade básica [Internet]. São Paulo: Hucitec; 1996 [cited 2019 Sep 12]. Cap. 1, p. 29-47. Available from: http://www2.fm.usp.br/gdc/docs/preventivapesquisa_130_saude_cap_1.pdf

29. Ramos CFV, Araruna RC, Lima CMF, Santana CLA, Tanaka LH. Education practices: research-action with nurses of Family Health Strategy. Rev Bras Enferm. 2018;71(3):1144-51. doi: 10.1590/0034-7167-2017-0284

30. Santos TVC, Penna CMM. Daily demands in primary care: the view of health professionals and users. Texto Contexto Enferm. 2013;22(1):14956. doi: 10.1590/S0104-07072013000100018

31. Tristão FI, Lima RCD, Lima EFA, Andrade MAC. [Accessibility and use in primary health care: reflections about user's absenteeism]. Rev Bras Pesqui Saúde. 2016;18(1):54-61. doi: 10.21722/rbps.v18i1.15134 Portuguese. 
32. Fonseca AF, Corbo AMD. O território e o processo saúde-doença [Internet]. Rio de Janeiro: EPSJV/Fiocruz; 2007 [cited 2019 Aug 30]. Available from: http://www.epsjv.fiocruz.br/sites/default/files/l24.pdf

33. Santos DS, Tenório EA, Brêda MZ, Mishima SM. The health-disease process and the family health strategy: the user's perspective. Rev LatinoAm Enfermagem. 2014;22(6):918-25. doi: 10.1590/0104-1169.0002.2496

34. Neves RG, Flores TR, Duro SMS, Nunes BP, Tomasi E. Time trend of family health strategy coverage in Brazil, its Regions and Federative Units, 2006-2016. Epidemiol Serv Saúde. 2018;27(3):e2017170. doi: 10.5123/S1679-49742018000300008 